\title{
The Effect of Playing Dol Musical Instruments to the Musical Intelligence of Children Aged 4-5 Years in PAUD Haqiqi, Bengkulu City
}

\author{
Fatrica Syafri $^{1, *}$, Wira Hadi Kusuma ${ }^{2}$ and Fatrida Anugrah Syafri ${ }^{1}$ \\ ${ }^{1}$ Lecturer of Early Childhood Islamic Education Study Program, IAIN Bengkulu, Indonesia \\ ${ }^{2}$ Lecturer of Islamic Communication, IAIN Bengkulu, Indonesia \\ *Corresponding author.Email: fatricasyafri@iainbengkulu.ac.id
}

\begin{abstract}
The issue that arises is the lack of interest in playing the Dol. The child still does not understand the Dol's beat, sound, and rhythm, lack of compactness when a Dol is played in children, and lack of excitement for children while playing a Dol in following the movements. The goal of this study was to determine the impact of playing the Dol in PAUD Haqiqi Bengkulu City on the musical intelligence of children aged 4-5 years. Quantitative research with a quasiexperimental approach using a pretest-posttest control group design is the type of research used. The samples were taken using purposeful sampling technology. A portfolio sheet and a checklist were used for the instrument. In this study, data collection techniques used observation techniques and documentation techniques as well as techniques for data analysis using the run test formula. Based on data review and discussion of research findings, it can be concluded that playing the Dol instrument in PAUD Haqiqi Bengkulu City has been shown to have an effect on the musical intelligence of children aged 4-5 years. This can be seen from the findings at the time of the study of the pretest and posttest experimental and control classes. In the experiment, it proved to have risen far higher than the control group. In the experimental treatment, there was an increase of $70 \%$ from the previous pretest results of $33 \%$ with the provision of treatment using the Dol musical instrument playing method, which increased $95 \%$ while at the time the treatment did not use the playing musical instrument method, it decreased 54\% from the previous pretest results of $66 \%$ in the presence of the treatment did not change.
\end{abstract}

Keywords: Playing Dol, Musical Intelligence, Children.

\section{INTRODUCTION}

According to law no. 20 of 2003 concerning the National Education System related to early childhood is written in article 28 paragraph 1 which reads "early childhood education is held before the basic education level" further chapter 1 article 1 paragraph 14 states that "Early childhood education is a coaching effort aimed at children from birth to six years of age which is carried out through the offering of stimuli to assist physical and spiritual growth and development so that the child has the readiness to enter further education."

The range of early childhood from birth to six years is a critical age as well as a strategy in the educational process and can affect the process and results of one's subsequent education, meaning that this period is a conducive period for developing various abilities, intelligence, talents, physical, cognitive, and language abilities, social, emotional, and spiritual [1].
So, it can be inferred that education must be done early in order to produce a smart and quality generation, and one way to start is by coordinating early childhood education institutions in our society so that early childhood intelligence can be established optimally. Children have numerous abilities and intelligence levels and some of them have not only intelligence. Every child is born with promise and talents of their own [2].

In the book of Takdiroatun Musfiroh, according to Howard Gardner, there are many different bits of intelligence (multiple intelligences) that have been clarified. Early childhood education and teachers are hoped to be a successful mean of improving the intelligence of children, if the intelligence of the child is underdeveloped it will affect the social-emotional development of the child, so that the child will encounter difficulties and delays in their socialemotional development, especially in their relationship with other people [3]. 
Educators and parents should observe all the progress of these factors in the development phase, but improving the development of children's intelligence can be followed by developing behaviors, mental selfconfidence, and the development of social sensitivity. Children between the ages of 4 and 6 have a greater ability to optimize all abilities and knowledge, including musical skills, resulting in musical intelligence for children.

Intelligence can be gained by self-taught learning or tutoring in the abilities to play a musical instrument, and extracurricular music education schools in the curriculum in Indonesia are still far from adequate. Music is just an aspect of the subjects of craft and art. In infants, musical intelligence is one of the different bits of intelligence that need to be enhanced. Learning and teaching strategies in Islam are inseparable from the main source of teaching, namely the Qur'an, which has given an overview of education especially learning strategies and teaching strategies, as a guide and guidance for people. Below is a verse of the Qur'an which from the point of view of the Qur'an is related to teaching and learning methods related to the Qur'an system of learning and teaching. Allah's Phrase SWT:

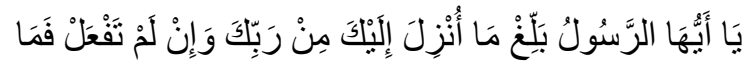

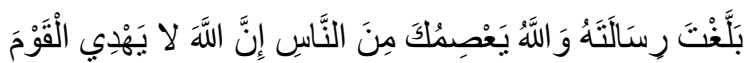

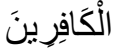

Meaning:

O Messenger, announce that which has been revealed to you from your Lord, and if you do not, then you have not conveyed His message. And Allah will protect you from the people. Indeed, Allah does not guide the disbelieving people. (QS. Al-Maidah 67) [4].

There is also a hadith about the development of a conducive learning environment in addition to the above verses of the Al Qur'an. Allah has also demonstrated learning in this case that is capable of creating an environment that is conducive and risk-free, for example by not being forced to accept Islam, but by knowledge and honesty. The ability to store notes, remember rhythms, and be influenced emotionally by music is musical intelligence. Music may therefore be referred to as an emotional language that can affect an individual. The ability to establish and perceive rhythms, tone point patterns, and rhythms, tone dot patterns, and tone colors, as well as the ability to perceive modes of musical expression, characterizes musical intelligence. Someone who is optimal in this intellect appears to like and be effective in writing, singing, and whistling melodies and also lyrics.

In general, musical talent is characterized as an inherent capacity for musical reactions, as an ability that needs to be cultivated and educated. It is predicted that children will learn music because it can enhance intelligence and increase the interest of children in learning. One that can be identified is music, so that musical intelligence grows well in children. This may develop aspects of development and musical intelligence in children by playing a Dol musical instrument. Based on the results of researchers' observations made at PAUD Haqiqi, Bengkulu City on April 24, 2018, it was found that there was a lack of interest from children in playing the Dol, lack of compactness when a Dol is played in children, and lack of excitement for children while playing a Dol in following the movements. If the child can play a Dol musical instrument, understand the beat, sound, and rhythm of a Dol, the aspect to be studied is when the child keeps, hits, and plays the Dol musical instrument in the coordination aspect that will be observed. The reason for this study is important to be able to find out how children play musical instruments and to enhance early childhood musical intelligence, researchers are also encouraged to learn the art of Dol. Based on this context, the author will conduct research in HAQIQI PAUD, Bengkulu Region, selecting a topic of the effects of playing Dol musical instruments on the musical intelligence of children aged 4-5 years.

\section{THEORETICAL REVIEW}

Play is an early childhood human right that has the primary and fundamental importance of the pre-school age. Early childhood playing experiences are very significant in the growth of their personality. Playing for a kid is not only filling time but learning for kids is a medium. Children can grow gross and fine muscles while playing, enhance logic, and understand the nature of their world, imagination, fantasy strength, and creativity [7]. To stimulate those skills and abilities in children, play can be used as a tool [8]. Playing is described in language as a direct or spontaneous operation. They are performed for fun or on their own initiative as children communicate with others, use creativity or imagination, and use all their limbs.

Playing may also mean that for the amusement that is produced and without considering the final result, each operation is carried out [9]. Play provides children with opportunities to understand the world, connect with others, convey and control feelings, and improve their symbolic capabilities. Play provides children with opportunities to understand the world, connect with others, convey and control feelings, and improve their symbolic capabilities [10]. Playing is a natural and instinctive process that, mostly during development, acts as nutrition for children's physical and psychological health. Move and speak activities is an effective method and learning process for children, a process of learning that is not the same as formal school learning. Children will feel good by playing. This feeling of pleasure 
stimulates the nerves of the brain of the infant to link to each other, producing a new memory.

The Dol is a popular Bengkulu Province drum instrument. The Dol musical instruments are commonly made from coconut trees using wood or weevils. Some make it from the jackfruit tree occasionally. The coconut tree stump is perforated in the center during manufacture and filled as a sound membrane with cow or goat skin [11].

Meanwhile, the early childhood Dol has a wide Dol with a $50 \mathrm{~cm}$ diameter and a $50 \mathrm{~cm}$ height. Little Dol is between 25 and $30 \mathrm{~cm}$ tall. The way to use it is by using a batting aid to be struck. Other instruments such as a bat made from wooden stalks and in the center of a round $\log$, Tassa (tambourine) which is useful for leading large and small Dol, Serunai/flute for the rhythm of the music are used to play the Dol musical instrument for early childhood.

Dol was first brought in from India by traders. The type is more like a cowhide drum. Dol was only played during Tabot celebrations in the past, every 1-10 Muharram to remember the deaths of Imam Hasan and Imam Husen (Prophet Muhammad's grandson) [12]. In the Padang Karbala War. Every year this ceremony is still carried out because it is believed to be able to prevent different problems and outbreaks of disease. Not just anybody but descendants of Tabot, are people who become Dol musicians, namely Bengkulu residents of Indian descent who are commonly called Sipai. Indeed, the Indian Muslim community that came to Indonesia under the British colonial government, who built Fort Marlborough at that time introduced Dol for the first time. The local Bengkulu people were later married and their ancestry was known as the Tabot tribe. Dol music was only allowed to be played by people who were related to the Tabot family by blood until the 1970s. The customs and practices have long been "restrained". Dol music is now used as accompaniment in various special events along with the times and efforts of many local artists who want to bring exclusive Dol music to the broader community. Demand, ranging from children to adults, is also increasingly common. In groups in houses or art studios, they also play Dol. There is also frequently featured in neighboring countries in art events [13].

Tassa built like a tambourine, made of copper, plate iron, or aluminum, and can also be made of a cauldron whose surface is covered with dried Goatskin, Boya is a small Dol, a large Dol is shaped like a drum, and a flute is the musical instrument that accompanies the playing of Dol.

Serunai played with a blow and a bat in the middle made of wood and a round. The teacher teaches children how to play the Dol musical instrument, such as how to carry, hit the Dol musical instrument, assisted by other aids such as flute, Serunai, tambourine, bat, and small Dol, before beginning the activity. The instructor then splits the party into each of the kids who play the big Dol, tiny tambourine Dol, and other aids. Then, tell each child to use a bat accompanied by a tambourine, Serunai, and other aids to keep and play the Dol musical instrument according to the beat of a simple musical rhythm while playing the Dol musical instrument, tell the child to use the rhythm of Islamic songs, namely the prayer song of the prophet accompanied by Dol music. The teacher assesses each child after that.

Musical intelligence is the ability, with sound intonation, rhythm and tone color, to hear and recognize patterns, remember, and respond according to the music heard, and create music. Musical intelligence involves sound pattern sensitivity, patterns, tonal colors, and sounds sensitive to non-verbal sounds in their environment, such as singing, humming, or whistling alone. It is considered that people with musical intelligence have a deep knowledge of music, easily remember songs and melodies, have an understanding of tonal color and arrangement, can discern between tonal patterns, and enjoy being immersed in music in general. In this case, as quoted by May Lwin, Plato claimed that everyone has a "Window of the Heart" to feel something when music communicates something.

In other words, music can be a way of improving one's intellect because it is possible to capture music signals more profoundly, learning lasts longer, perform more enthusiastically, and the heart is content. In this scenario, music is a music that has a normal rhythm with regular tones. Good music can help promote the development of the intellect of different children. In music, children who are smart will enjoy singing, knocking on desks, clicking their fingers, nodding their heads to the music beat.

The core components of musical intelligence include note awareness, note points or scale patterns, rhythms, colors, and the sound of a song. Thus, one can discern tones by tone sensitivity and can also judge which notes are false and which are not. Note-point pattern sensitivity helps kids to recognize those songs, follow the rhythm, and respond accordingly. Sensitivity to tone and sound colors, meanwhile, enables children to be able to correctly identify sound sources or sound owners.

The ability to store notes, remember rhythms, and be influenced emotionally by music is musical intelligence. Music can provide a sense of fulfillment and relaxation and is therapeutic. Music helps kids to get the chance to express themselves. Music also gives children opportunities to release suppressed feelings or release emotions that their world cannot tolerate. In this section the researcher will discuss the theory of playing Dol, which is linked to musical intelligence, a research must be supported by theory as a basis for comparison so that it can be well guided. The Cognitive Theory of Jean 
Piaget suggests that through their interactions, children build their own knowledge of their environment, practice using information they have learned before by mixing new information with familiar skills, and also test their experiences with new ideas. This means that by playing the Dol, musical intelligence can be created because by playing kids can learn new experiences that have been gained and train the skills of children. Children can communicate with new friends by playing. In this section the researcher will address the theory of playing Dol, which is linked to musical intelligence. A study must be supported by theory as a basis for comparison so that it can be well guided.

The Cognitive Theory of Jean Piaget suggests that through their interactions, children build their own knowledge of their environment, practice using information they have learned before by mixing new information with familiar skills, and also test their experiences with new ideas. This implies that by playing the Dol, musical intelligence can be created because by playing kids can learn new experiences that have been gained and train the skills of children. Children communicate with new friends by playing.

\section{RESEARCH METHOD}

In the Arousal Modulation theory, the above theory is also in line with Ellis' opinion that considers play as a "stimulation-seeking behavior (stimulus) that can optimally enhance motivation. Playing adds stimulation through the use of new and uncommon objects and acts." That is if children also do things that can stimulate intelligence; the stimulation of the child will increase.

The experimental model has various research designs. In this study, the design used was a QuasiExperimental with the experimental pretest-posttest control group design, namely the comparison of the two control groups and the experimental group used in this type. Experimental research is research that is used to find the effect of certain treatments on others under controlled conditions and the presence of control.

\section{RESULTS AND DISCUSSION}

The results of the study show that in PAUD Haqiqi Bengkulu City, there is an effect of playing a Dol musical instrument on the musical intelligence of 4-5year-old children. The effect of playing Dol musical instruments on the musical intelligence of children aged 4-5 years in PAUD Haqiqi, Bengkulu City, is focused on research conducted by researchers. One way to develop the musical intelligence of a child is the practice of playing a musical instrument, for any way the teacher does would be followed by children from singing while playing a percussion instrument, to simply aligning song lyrics with a Dol.
Musical intelligence is the ability, with sound intonation, rhythm and tone color, to hear and recognize patterns, remember, and respond according to the music heard, and create music. Musical intelligence involves sound pattern sensitivity, patterns, tonal colors, and sounds sensitive to non-verbal sounds in their atmosphere, such as singing, humming, or whistling alone. Based on the findings of researchers in PAUD Haqiqi, Bengkulu City, on effect of playing Dol musical instruments on children's musical intelligence for 4-5 years, treatment was administered by conducting research using the experimental group, while treatment was not offered to the control group.

The data analysis methodology used is to find out the effects of the data obtained by the researcher through observation and documentation techniques using quantitative methods using the run test formula.

In PAUD Haqiqi, Bengkulu City, the ability to play Dol musical instruments at early childhood can be said to be moderate because there were some children who were less interested in playing traditional musical instruments when the researchers made direct observations. Whether the child can play the Dol musical instrument, understand the beat, tone, and rhythm of the Dol musical instrument in the coordination aspect to be observed is the aspect to be studied when the child keeps, hits, and plays the Dol musical instrument. Researchers used a Dol musical instrument in the research process, hoping that it would enhance the musical intelligence of children 4-5 years in PAUD Haqiqi, Bengkulu City.

The Cognitive Theory of Jean Piaget argues that "children create their own understanding of their environment through their interactions, they practice using the knowledge they have learned before by mixing new information with familiar skills, they also test their experiences with new ideas." This means that by playing the Dol, musical intelligence can be created because by playing with children can learn.

In order to develop those abilities and skills in children, play may be used as a tool. Play is characterized in language as a direct or spontaneous operation. When children interact with other individuals, do it with fun or on their own initiative, use creativity or imagination, and use all of their limbs. From the study conducted at PAUD Haqiqi, Bengkulu City by researchers. Previously, the researcher first explained the Dol musical instrument's operation and how to play it then the researcher explained how to hold, hit, and play a simple Dol musical instrument to the child. Then with each child, the researchers shared the Dol. The researcher then asked the child to beat and play their respective Dol musical instrument after the child held a Dol musical instrument. 
In PAUD Haqiqi, Bengkulu City, the results of the pre-test and post-test discussion of the effect of playing the Dol on the musical intelligence of children aged 4-5 years were shown to experience a much greater increase in experimentation compared to the control group. In the experimental treatment, there was an increase of $70 \%$ from the previous pretest results of $33 \%$ with the provision of treatment using the Dol musical instrument playing method, which increased by $95 \%$. At the time the treatment did not use the method of playing a musical instrument, it decreased 54\% from the previous pretest results of $66 \%$ in the presence of the treatment there was no change.

\section{CONCLUSION}

Based on data analysis and discussion of research results, it can be concluded that playing the Dol instrument is proven to have an effect on the musical intelligence of children 4-5 years in PAUD Haqiqi Bengkulu City. This can be seen from the results of the pretest and posttest experimental and control groups at the time of the study proved to have increased in the experiment much higher than the control group.

\section{ACKNOWLEDGMENTS}

This research is supported by the IAIN Bengkulu through the Teacher Training and Education Faculty, PAUD Study Program, Lecturers who teach the Seni Musik dan Menyanyi Bagi AUD and Multiple Intelligence.

\section{REFERENCES}

[1] A. Devianti, Panduan Lengkap Mencerdaskan Otak Anak Usia 1-6 Tahun, Yogyakarta:PT Araska, p. 43, 2013.

[2] A. Yus, Model Pendidikan Anak Usia Dini, Medan: PT. Kencana Prenada Group, p. 72, 2010.

[3] B. Delphie, Psikologi Perkembangan Anak Berkebutuhan Khusus, Yogyakarta: PT.Intan Sejati Klaten, p. 31, 2009.

[4] D. Mutiah, Psikologi Bermain Anak Usia Dini, Jakarta: Rektor, p. 170, 2012.

[5] M. Tadkirotun, Pengembangan Kecerdasan Majemuk, Jakarta: Universitas Terbuka, p. 112, 2009.

[6] M. Tadkiroatun, Kecerdasan Majemuk, Jakarta: Universitas terbuka, p. 19, 2008.

[7] M. Yaumi \& Nurdin Ibrahim, Pembelajaran Kecerdasan Jamak (Multi Intelegences) Mengidentifikasi dan Mengembangkan
Multitalenta Anak, Jakarta: PT. Kencana Group, p. 117, 2013.

[8] N. Ardy Wiyani, Konsep Dasar PAUD, Yogyakarta: PT. Gava Media, p. 1, 2016.

[9] N. Ardy Wiyani, Manajemen PAUD Berdaya Saing, Bandung: PT. Gava Media, p. 16, 2017.

[10] Sugiyono, Metode Penelitian Kuantitatif, Kualitatif, dan R\&D, Bandung: PT.Alfabeta, p. 72, 2014.

[11] Suyadi, Teori Pembelajaran Anak Usia Dini Dalam Kajian Neurosains, Bandung: PT. Rosdakarya, p. 130-131, 2014.

[12] T. Utama, Ensiklopedia Alat Musik Tradisional, Bandung: PT.CV. Angkasa, p. 32, 2014.

[13] Y. Rachmawati \& Euis Kurniati, Strategi Pengembangan Kreativitas Pada Anak Usia Taman Kanak-kanak,. Jakarta: PT. Kencana Pranada Group, p. 24, 2010. 